\title{
Mercury Determination in Biological Organism in the Estuary of Muar River, West Johor, Malaysia
}

\author{
M.M. RAHMAN ${ }^{1}$, R.H. ANSARY ${ }^{1}$, M.M. FUAD², B.Y. KAMARUZZAMAN² and W.B. WAN NIK ${ }^{3 *}$ \\ 1'Department of Pharmaceutical Chemistry, Kuliyyah of Pharmacy, \\ International Islamic University Malaysia, 25200 Kuantan, Pahang, Malaysia. \\ ${ }^{2}$ Department of Biotechnology, Kuliyyah of Science, \\ International Islamic University Malaysia, 25200 Kuantan, Pahang, Malaysia. \\ ${ }^{3}$ School of Ocean Engineering, Universiti Malaysia Terengganu, \\ 21030 Kuala Terengganu, Malaysia. \\ *Corresponding author E-mail: niksani@umt.edu.my \\ http://dx.doi.org/10.13005/ojc/320541
}

(Received: June 04, 2016; Accepted: September 12, 2016)

\begin{abstract}
Determination of Mercury in Biological Sample in Muar River Estuary, West Johor, Malaysia. This study was carried out at the Estuary of Muar River, west Johor, Malaysia. Different types of biota species namely Crassostrea irredalei, Perna viridis and Anadara granosa were collected all through the torrential rainy season in November 2005. These biota species were dried and then cooked in an acid solution for Cold Vapour Atomic Absorption Spectrometric (CV-AAS) analysis. CV-AAS) was used for decisive the mercury $(\mathrm{Hg}++)$ concentration in the collected biota species. The average $\mathrm{Hg}++$ concentration in C. irredalei, $P$. viridis and $A$. granosa were $1.854 \pm 1.012 \mu \mathrm{g}$ $\mathrm{g}^{-1}, 0.336 \pm 1.125 \mu \mathrm{g} \mathrm{g}^{-1}$ and $1.178 \pm 1.182 \mu \mathrm{g} \mathrm{g}^{-1}$ respectively. These results directed that the biota especially $C$. irredalei and $A$. granosa are contaminated by $\mathrm{Hg}++$ and these are not safe to be consumed for publicly used due to the total $\mathrm{Hg}++$ concentration exceeding $0.5 \mu \mathrm{g} \mathrm{g}^{-1}$ according to WHO.
\end{abstract}

Keywords: biota, CV-AAS, mercury concentration.

\section{INTRODUCTION}

Mercury is considered as global pollutant element and many of its compounds are highly toxic and readily released into the environment because of their high volatility and mobility. Mercury is one of the hazardous, prevalent and toxic elements to the environment ecosystem. This element can be present as diverse dissolved chemical species in natural water as well as rivers, lake and ocean. Inorganic and organic species of mercury are generated in different industrial activities, mainly pharmaceutical, paper, electrochemical (batteries) and plaguicide industries (Mason and Fitzgerald, 
1990). According to Regional Water Quality Control (RWQC), the source of mercury come from residents $(46 \%)$, water supply $(22 \%)$, dentist $(9 \%)$, storm water $(3 \%)$, permitted industries $(6 \%)$, unknown sources $(11 \%)$ and employee-related human waste $(3 \%)$. Although mercury is distributed throughout the environment, its toxic effects result mainly from ingestion of contaminated seafood. Unlike many other air pollutants, mercury residence times in the atmosphere are long and it may eventually be dispersed over large areas. As a result, adverse effects must be considered on both local and regional scales.

Trace metal bound to certain phases of the sediment are likely to be in thermodynamic equilibrium with the associated pore waters. These metals are likely to be those bound at surface adsorption sites in sulphide or organic phases, rather than those occluded within mineral phases (Fikriah et al. 2014). Adsorption occurs during sedimentation and re-suspension of particulates. Interaction of biota with natural sediment constituent and contaminants occurs at several atrophic levels (Suhaimi et al. 2012).

In recent years, several author have reported on the usefulness of the common mussel as a biology indicator of heavy metal contamination in coastal waters, Mussels may accumulate these elements from ingested food material and sea water to concentration greatly excess of those found in their environment and to an extent which is related to the content of available metals in water. Since they are also worldwide distribution, Goldberg proposed the use of mussel as indicator organism for the global marine pollution monitoring programmed (Goldberg, 1978).

Muar river estuary is located at Johor, Malaysia lied in the proximity of industries area, primer forest and the town of Muar, Bandar Maharani. Muar river estuary is a famous place for seafood and even seafood source such as oysters, fish, and blood cockle. Thus there is a need to carry out a study to determine the mercury concentration in the water due to the development of the industrial areas at this river. Industries areas have a high tendency to send the pollutant to the Muar River Estuary and cause water contamination which lead to the aquatic organism bioaccumulation via food chain. The aims of this study are to gain an insight on the level of total mercury that accumulated in biological samples from Muar River Estuary, Johor.

\section{MATERIALS AND METHODS}

\section{Reagent Preparation}

Bromine monochloride $(\mathrm{BrCl})$ was prepared by adding $10.8 \mathrm{~g}$ of reagent grade Potassium bromide $(\mathrm{KBr})$ into 1 liter volumetric flask containing 1 liter of concentrated hydrochloric acid $(\mathrm{HCl})$ and stirred for an hour with stir bar. $15.2 \mathrm{~g}$ reagent grade Potassium Bromate $\left(\mathrm{KBrO}_{3}\right)$ was added slowly while stirring. This process will produce large free halogens and the color will change from yellow to red then yellow. Finally, the solution was allowed to stir for another addition hour. For Hydroammonium chloride $\left(\mathrm{NH}_{2} \mathrm{OH}\right.$. $\mathrm{HCl})$ solution, it was prepared by adding $30 \mathrm{~g}$ of $\mathrm{NH}_{2} \mathrm{OH} . \mathrm{HCl}$ into deionized water in $100 \mathrm{ml}$ volumetric flask and the solution was purged with mercury free nitrogen. Tin chloride solution was prepared by dissolving $25 \%$ Tin (II) chloride $\left(\mathrm{SnCl}_{2}\right.$ in $20 \% \mathrm{HCl}$ by heating. For potassium bromide, it was prepared by diluting $10 \mathrm{~g}$ of potassium bromide into $100 \mathrm{ml}$ deionized water and mixed well.

\section{Sampling collection and preparation}

The sampling stations located at Muar River Estuary, Johor is very unique due to the existence of industrial areas, primary forests and township of Muar around. The industrial and town area are located oppositely while mangrove is located near to sea. The types of industry laid at sampling area included semiconductor industries, steel mill industries, electrical industries, distillery industries, food industries, and oil stations. 10 sampling sites were sampled on November 2005 during high tide (Figure 1) within monsoon season. In situ water parameter was measured using Hydrolab before sample collection. Parameters that taken into account including temperature, conductivity, turbidity, salinity, dissolved oxygen, $\mathrm{pH}$ and depth. Biota sample was hand collected. All samples were placed in plastic bags, sealed, labelled and stored on ice for transportation to the laboratory.

Prior to sampling and laboratory analysis, all the glassware and equipment used were washed with tap water and distilled water before being immersed 
in $10 \%$ nitric acid $\left(\mathrm{HNO}_{3}\right)$ solution for at least 24 hours. Next, the container was taken out and soaked in $1.0 \%$ hydrochloric acids solution to remove all trace of oxidizing compound that can destroy and stored double-bagged until used (Nguyen et al., 2005)

\section{Analytical Method}

Biological samples were dried at $60^{\circ} \mathrm{C}$ until constant weights were reached. $0.5 \mathrm{~g}$ of each sample was weight in Teflon beaker and placed on the hot plate. $4 \mathrm{ml}$ of nitric acid $\left(\mathrm{HNO}_{3}\right)$ was added followed with $2 \mathrm{ml}$ sulfuric acid $\left(\mathrm{H}_{2} \mathrm{SO}_{4}\right)$. The sample was heated constantly for 3 hours at $90^{\circ} \mathrm{C}$ temperature. $1 \mathrm{ml}$ of $10 \%$ potassium dichromate $(\mathrm{w} / \mathrm{v}) \mathrm{K}_{2} \mathrm{Cr}_{2} \mathrm{O}_{7}$ was added at the end of heating process. The samples were then brought to $50 \mathrm{ml}$ volume with deionized water and $2 \mathrm{ml}$ of Tin (II) chloride $\left(\mathrm{SnCl}_{2}\right)$ was added.

Analysis of total mercury was carried out using CV-AAS in its standard configuration. Results were quantified via an external calibration curve generated from the responses obtained from multiple dilutions of a single element calibration standard that was prepared from $1000 \mu \mathrm{g} \mathrm{L}^{-1}$ mercury standard stock solution (Merck).

Concentration of mercury in biological samples was calculated by using the formula below:

Metal conc. $=\underline{\text { Concentration }\left(\mu \mathrm{g} \mathrm{m}^{-1}\right) \times \text { dilution volume }(50 \mathrm{ml})}$ ( $\mu \mathrm{g} \mathrm{g}^{-1}$ dry weight) Weight of dry sample $(\mathrm{g})$
Detection of total mercury in biota samples that carried out using CV-AAS was blank corrected and expressed as $\mu \mathrm{g} \mathrm{g}^{-1}$ dry weight. Blank sample was used to investigate any effect of contaminant of mercury derived from instrument, environment or calculation error. Acid solution without actual biota sample was organized in a similar way for digestion process. The actual concentration of samples was produced by subtracting the values of the blank from the values obtained by the detection reading.

The recovery test was carried out and checked in a separate comparative study and undergo the same procedure of sample. Recovery test was checked using spike method. Recoveries obtained was $93.65 \%$.

\section{RESULTS AND DISCUSSION}

The highest temperature was achieved at the mangrove and the lowest was found in industrial area. Generally, the result shows similar average temperature among all stations. There was significant different among all stations $(p<0.05)$.

There was significant difference observed in the conductivity among all stations $(p<0.05)$. The conductivity reading was ranged from $22.20 \mu \mathrm{s} \mathrm{cm}^{-1}$ to $46.03 \mu \mathrm{sm}^{-1}$ in which the highest conductivity was achieved by station 10 (mangrove area) and the lowest was station 2 (industrial area). From the result obtained, the conductivity increased from industrial area at upstream to the mangrove zone at

Table 1: Hydrology parameters from 10 sampling sites from Muar River Estuary, Johor

\begin{tabular}{|c|c|c|c|c|c|c|c|}
\hline Station & $\begin{array}{c}\text { Temperature } \\
\left({ }^{\circ} \mathrm{C}\right)\end{array}$ & $\begin{array}{l}\text { Conductivity } \\
\text { (is } \mathrm{cm}^{-1} \text { ) }\end{array}$ & $\begin{array}{l}\text { Turbidity } \\
\left(g^{-1}\right)\end{array}$ & $\begin{array}{l}\text { Salinity } \\
\text { (ppt) }\end{array}$ & $\begin{array}{c}\text { Dissolved } \\
\text { oxygen }\left(\mathrm{mg} \mathrm{L}^{-1}\right)\end{array}$ & $\mathrm{pH}$ & $\begin{array}{l}\text { Depth } \\
\text { (m) }\end{array}$ \\
\hline 1 & 29.12 & 24.01 & 14.46 & 13.32 & 5.00 & 6.71 & 1.71 \\
\hline 2 & 29.03 & 22.20 & 13.92 & 12.78 & 5.28 & 6.77 & 1.59 \\
\hline 3 & 29.22 & 35.26 & 21.18 & 21.23 & 5.97 & 7.05 & 2.09 \\
\hline 4 & 28.70 & 29.95 & 18.05 & 19.96 & 6.03 & 7.07 & 2.07 \\
\hline 5 & 29.09 & 36.75 & 22.13 & 21.09 & 5.93 & 7.17 & 1.72 \\
\hline 6 & 29.10 & 34.38 & 21.32 & 21.79 & 6.23 & 7.29 & 1.84 \\
\hline 7 & 28.97 & 41.17 & 25.46 & 24.81 & 6.34 & 7.44 & 1.91 \\
\hline 8 & 29.83 & 45.42 & 27.12 & 26.64 & 6.83 & 7.75 & 1.97 \\
\hline 9 & 29.62 & 45.92 & 27.42 & 29.96 & 6.36 & 7.93 & 1.90 \\
\hline 10 & 29.63 & 46.03 & 27.49 & 27.04 & 6.47 & 8.03 & 2.10 \\
\hline
\end{tabular}


downstream. Conductivity became higher when the station closer to open mouth of estuary to coastal, such as in mangrove zone. Salinity measurement increased constantly from station 1 to station 10 . The highest salinity was recorded at mangrove and lowest salinity was found in industrial area, ranging from 12.78 ppt to 29.96 ppt. Mangrove exhibited relatively high salinity reading compared to other locations. Higher salinity in mangrove may due to its location nearby the coastal and influenced by sea-level. There was significant different among all stations $(p<0.05)$.

As the sampling point getting closer to the mouth of estuary, the dissolved oxygen increased constantly from industrial area to mangrove zone. The lowest dissolved oxygen reading was showed by station $1\left(5.0 \mathrm{mgL}^{-1}\right)$ and the highest was found in station $8\left(6.83 \mathrm{mgL}^{-1}\right)$. Higher dissolved oxygen level in mangrove indicates an adequate supply

Table 2: Mean concentration of mercury in biological samples from Muar River Estuary

Table 3: Ratio of mercury in water and biota (Fowler, 1988)

\begin{tabular}{lccc}
\hline $\mathbf{n}$ & Sample & $\begin{array}{c}\text { Mean concentration } \\
\left(\boldsymbol{\mu} \mathbf{g ~ g}^{-1}\right)\end{array}$ \\
\hline 11 & Crassostrea iredalei & 1.854 & 1.012 \\
9 & Perna Viridis & 0.366 & 1.125 \\
5 & Anadara granosa & 1.178 & 1.182 \\
\hline
\end{tabular}

\begin{tabular}{lc}
\hline Range & Classification \\
\hline $1-10$ & Accumulation \\
$11-50$ & Moderately accumulation \\
$50-100$ & Severely accumulation \\
$>100$ & DNA structure different
\end{tabular}

Table 4: Regression analysis total mercury and various parameters

\begin{tabular}{cccccc}
\hline & Temperature & Salinity & $\begin{array}{c}\text { Dissolved } \\
\text { oxygen } \\
\mathbf{R}^{2}\end{array}$ & $\begin{array}{c}\mathbf{p H} \\
\text { (sediment) }\end{array}$ & Turbidity \\
\hline Mercury & 0.8701 & 0.7483 & 0.9777 & 0.1638 & 0.8312 \\
\hline
\end{tabular}

and available of oxygen to support marine species growth and activity. Dissolved oxygen level is controlled by water mixing, temperature, salinity and decomposition of organic matter. $\mathrm{pH}$ values at Muar River Estuary was constantly increased from station 1 to station 10. The $\mathrm{pH}$ values were in between 6.71 to 8.03 , which mangrove area has the highest $\mathrm{pH}$ value while industrial area has the lowest. The $\mathrm{pH}$ values for estuaries typically increase as salinity

Table 5: ANOVA test for biological samples

\begin{tabular}{ll}
\hline Samples & P-value \\
\hline C. iredalei & 0.000793 \\
P. viridis & 0.000115 \\
A. granosa & 0.083444 \\
\hline
\end{tabular}

Table 6: Comparison of mercury concentration in this study with other studies

\begin{tabular}{lll}
\hline Region & $\begin{array}{l}\text { Mercury } \\
\text { concentration }\end{array}$ & Reference \\
\hline $\begin{array}{l}\text { A. granosa } \\
\text { Penang }\end{array}$ & $0.001-0.049 \mu \mathrm{g} \mathrm{g}^{-1}$ & (Devi, 1986) \\
Selangor & $0.006-0.128 \mu \mathrm{g} \mathrm{g}^{-1}$ & \\
Perak & $0.029 \mu \mathrm{g} \mathrm{g}^{-1}$ & \\
Penang & $0.011-0.023 \mu \mathrm{g} \mathrm{g}^{-1}$ & (Jothy et al., \\
Perak & $0.007-0.065 \mu \mathrm{g} \mathrm{g}^{-1}$ & 1983) \\
Penang & $0.038-0.072 \mu \mathrm{g} \mathrm{g}^{-1}$ & \\
Thailand & $0.020 \mu \mathrm{g} \mathrm{g}^{-1}$ & (Phillips and \\
ADI (WHO) & $0.500 \mu \mathrm{g} \mathrm{g}^{-1}$ & Rainbow, 1989) \\
C. iredalei & $1.850 \mu \mathrm{g} \mathrm{g}^{-1}$ & This study \\
P. viridis & $0.366 \mu \mathrm{g} \mathrm{g}^{-1}$ & \\
A. granosa & $1.178 \mu \mathrm{g} \mathrm{g}^{-1}$ & \\
\hline
\end{tabular}


rises. This can be explained by go through the salinity measurement in this study area. Effect from seasonal also affects $\mathrm{pH}$ values. During monsoon season, the water flow in Muar River Estuary is fast, adds to the river natural flow and discharges pollutants into the water from surrounding. Runoff from domestic and industrial area may attribute to these $\mathrm{pH}$ levels recorded. No significant differences of dissolved oxygen and $\mathrm{pH}$ were found among stations $(p>0.05)$.

The turbidity showed linear increasing from station 7 to station 10 . Turbidity of industrial area and town area was not stable as somehow the water fluxes at upstream well mixed the water content more frequently than downstream. Hence, the water in industrial area and town area was clearer than mangrove, in which mangrove is nearly muddy and consisted of many suspended solids. There was significant different among all stations.

\section{Concentration of total mercury in biological samples}

Mercury concentration in biota samples from Muar River estuary ranged between $0.158-3.481 \mu^{-1} \mathrm{~g} \mathrm{~g}^{-1}$ dry weight while the mean mercury concentration, $0.366-1.854 \mu \mathrm{g} \mathrm{g}^{-1}$ dry weight (Table 2). C. iredalei and $P$. viridis was collected at station 2 while $A$. granosa was collected at station 8 . It was found that $C$. iredalei has the highest mercury concentration in contrast with $P$. viridis which are from the same station and A. granosa from the sea. However, $A$. granosa found to have higher mercury concentration compare with $P$. viridis. There was significant differences found in total mercury concentration among samples for

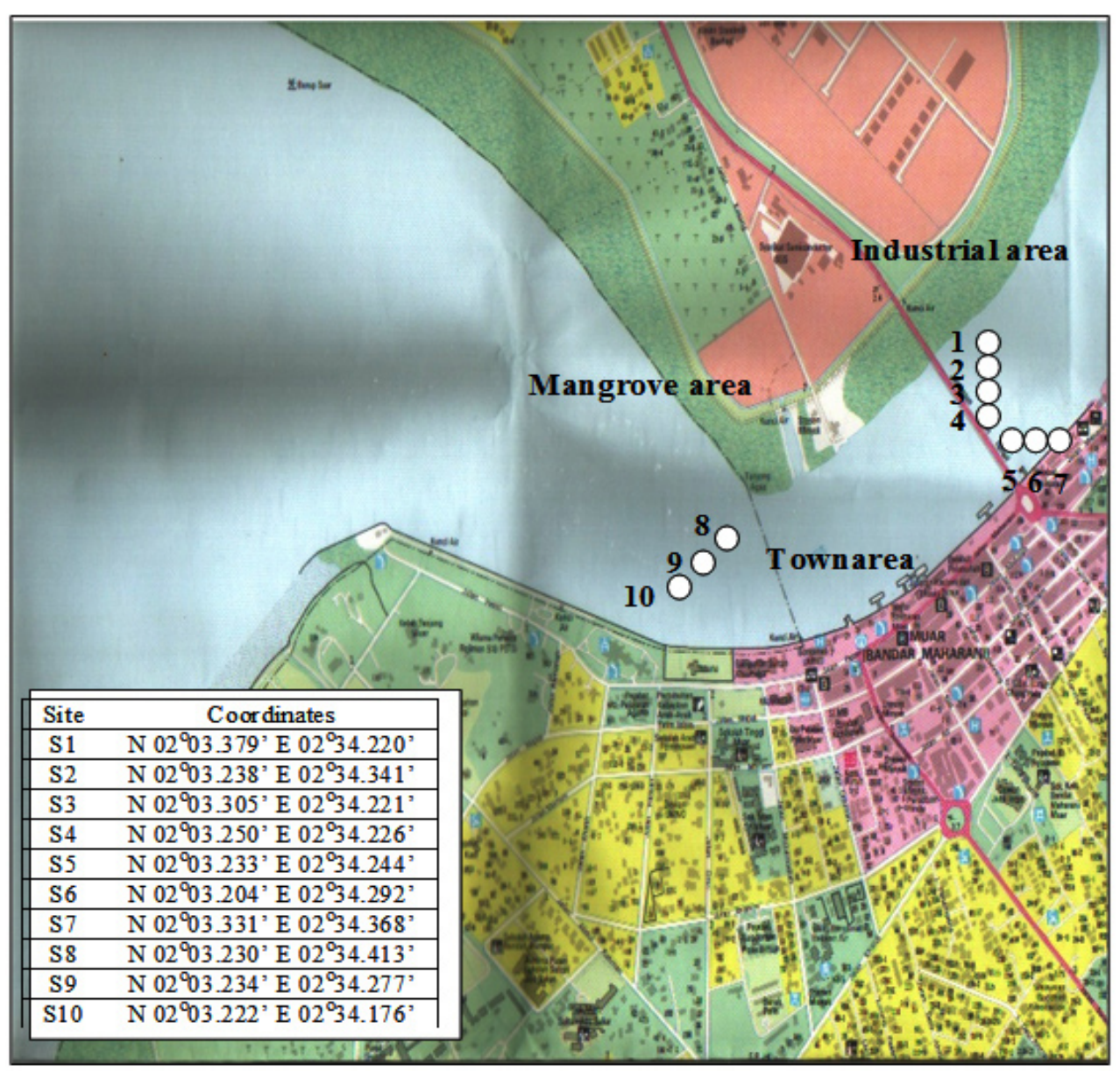

Fig. 1: 10 station locations with coordinates in Muar River Estuary, Malaysia 
Site Coordinates

S1 N 0203.379' E 02³4.220'

S2 N 02 $03.238^{\prime}$ E $02^{\circ} 34.341^{\prime}$

S3 N 02 $03.305^{\prime} \mathrm{E} 02^{\circ} 34.221^{\prime}$

S4 N 0203.250' E 02 ${ }^{\circ} 34.226^{\prime}$

S5 N 02 $03.233^{\prime}$ E $02^{\circ} 34.244^{\prime}$

S6 N 02 $03.204^{\prime}$ E $02^{\circ} 34.292^{\prime}$

S7 N 02 $03.331^{\prime} \mathrm{E} 02^{\circ} 34.368^{\prime}$

S8 $\quad \mathrm{N} 02^{\circ} 03.230^{\prime} \mathrm{E} 02^{\circ} 34.413^{\prime}$

S9 N 02 $03.234^{\prime} \mathrm{E} 02^{\circ} 34.277^{\prime}$

S10 N 02 $03.222^{\prime}$ E 02 $34.176^{\prime}$

C. iredalei and $P$. viridis $(p<0.05)$ while none was found for $A$. granosa $(p>0.05)$.

Analysis constructed to determine and classified the level of accumulation of the biota samples shows that $C$. iredalei, $P$. viridis and A.granosa have ratio of $5.80,1.15$ and 1.43 . This means that this biota were in the earlier stage of bioaccumulation level referred to the Table 3 .

The internal process of biological samples can strongly influence the organism metal concentration. Condition may influence by salinity and reproductive, tidal exposure and food supply. Size is the most important internal factor that may affect the accumulation rate of biological tissue. Smaller size of A. granosa proved to concentrate more mercury than the larger size (Fowler, 1988; Fowler et al., 1993). It can be concluded that accumulation rates might produce different results even the biological samples have similar body mass.

\section{Regression analysis}

The concentration of total mercury in sediment was influenced by temperature, salinity, dissolved oxygen and turbidity with the $\mathrm{R}$ square value in the range 0.1638 to 0.9777 (Table 4). Dissolved oxygen has a greatest influence on total mercury concentration compare to temperature, salinity and turbidity. $\mathrm{pH}$ does not influenced the concentration of total mercury in sediment due to the $\mathrm{R}$ square value lower than 0.5 .

The P-value for the biological samples was in the range 0.000115 to 0.083444 (Table 5). The null hypothesis for $C$.iredalei and $P$. viridis was fail to reject due to the P-value was lowest than 0.05 . These mean that the concentration of total mercury in the samples of $C$.iredalei and P.viridis was different. However, for $A$. granosa, the hypothesis was rejected. These mean that the concentration of total mercury in all samples was same.

\section{Comparison with previous studies}

Table 6 shows the concentration values of mercury from other studies. In comparing with biological samples from other areas in Malaysia, the mercury concentration in Muar River Estuary is very much higher. The concentration is also found to be higher than the acceptable daily intake standard of $0.500 \mu \mathrm{g} \mathrm{g}^{-1}$ particularly for oysters and cockles. Concentration of mercury in mussel is the only one lowest than the ADI (WHO) standard which is $0.500 \mu^{-1} g^{-1}$ (WHO, 1958).

\section{CONCLUSION}

The total mercury concentration in biota was between $0.366 \mu \mathrm{g} \mathrm{g}^{-1}$ to $1.854 \mu_{\mathrm{g} \mathrm{g}}{ }^{-1}$. From the data analysis, the dissolved mercury concentration in water was found to being influenced by the dissolved oxygen, $\mathrm{pH}$, salinity, turbidity and the water temperature. The accumulation of mercury in tissues of $C$. iredelei, $P$. viridis and $A$. granosa were found in the early stage. $C$. iredelei, and $A$. granosa in Muar River Estuary was contaminated with the total mercury and the concentration was above the ADI (WHO) level, $0.5 \mu \mathrm{g} \mathrm{g}^{-1}$ and considered not safe for consumption.

\section{ACKNOWLEDGEMENTS}

The author wishes to thank International Islamic University Malaysia and Universiti Malaysia Terengganu staff who provide helpful assistance during research progress.

\section{REFERENCES}

1. Goldberg, E.D. The mussel watch - A first step in global marine monitoring. Marine Pollution Bulletin.1978, 6(7), 111-114.
2. Devi, S. Heavy metal levels in some Malaysian shellfish. Fisheries Bulletin. 1986, 44, 13p.

3. Fikriah Faudzi, Yunus, Kamaruzzaman, 
Miskon, Mohd Fuad, Rahman, Md. Mokhlesur and John, Akbar Distributions of dissolved toxic elements during seasonal variation in Kuantan river, Pahang, Malaysia. Orient $J$ Chem, 2014, 30 (2). 479-484.

4. Fowler, S.W. Coastal baseline studies of pollutants in Bahrain, United Arab Emirates and the Sultanate of Oman. Proceedings Symposium on Regional Marine Pollution Monitoring and Research Programmes, Kuwait.1988, 155-180.

5. Fowler, S.W.; Readman, J.W.; Oregioni, B.; Villeneuve, J.P.; McKay, K. Petroleum hydrocarbons and trace metals in near shore Gulf sediments and biota before and after the 1991 war: An assessment of temporal and spatial trends. Marine Pollution Bulletin. 1993, 27, 171-182.

6. Jothy, A.A.; Huschenbeth, E.; Harms, U. On the detection of heavy metals organochloride pesticides and polychlorinated biphenyls in fish and shellfish from coastal waters of Peninsular Malaysia. Arch. Fish Disease.1983,33(3), 161-206.

7. Lee, H.L.; Mokthar, M.; Rusin, S. The bioaccumulation of trace metal by the freshwater snail, Turitele species, Found in the river of Borneo East Malaysia. Journal of biological science. 2004, 4(4), 441-444.
8. Mason, R.P.; Fitzgerald, W.F. Alkylmercury species in the Equatorial Pasific. Nature. 1990,347, 457-459.

9. Nguyen, H.L.; Leermakers, M.; Kurunczi, S.; Bozo, L.; Baeyens, W. Mercury distribution and speciation in Lake Balaton, Hungary. Science of the Total Environment. 2005,340(1-3), 231246.

10. Phillips, D.J.H.; Rainbow, P.S. Strategies of trace metal sequestration in aquatic organisms. Marine Environmental Research. 1989, 49, 83-93.

11. Sanchez Uria, J.E.; Sanz-Medel, A. Inorganic and methylmercury speciation in environmental samples. Talanta. 1998, 47(3), 509-524.

12. Suhaimi Md., Mohd Zahir and John, Akbar and Yunus, Kamaruzzaman and Khan Chowdhury, Ahmed Jalal and Saad, Shahbudin and Miskon, Mohd Fuad and Faudzi, Fikriah and Sa'ari, Anies Aznida, The distribution of selected metals in the surface sediment of Langkawi Coast, Malaysia. Oriental Journal of Chemistry, 2012, 28 (2). 725-732.

13. WHO, 1958. Guideline for the study of dietary intake of chemical contaminations. Geneva, World Health Organization (WHO) offset publication No. 87. 